\title{
MICROBIAL BIOSENSORS FOR ENVIRONMENTAL MONITORING
}

\author{
David VOGRINC ${ }^{1}$, Maša VODOVNIK ${ }^{2}$, Romana MARINŠEK-LOGAR ${ }^{3}$
}

Received September 10, 2015; accepted September 30, 2015. Delo je prispelo 10. septembra 2015, sprejeto 30. septembra 2015.

\section{Microbial biosensors for environmental monitoring}

Microbial biosensors are analytical devices capable of sensing substances in the environment due to the specific biological reaction of the microorganism or its parts. Construction of a microbial biosensor requires knowledge of microbial response to the specific analyte. Linking this response with the quantitative data, using a transducer, is the crucial step in the construction of a biosensor. Regarding the transducer type, biosensors are divided into electrochemical, optical biosensors and microbial fuel cells. The use of the proper configuration depends on the selection of the biosensing element. With the use of transgenic E. coli strains, bioluminescence or fluorescence based biosensors were developed. Microbial fuel cells enable the use of the heterogeneous microbial populations, isolated from wastewater. Different microorganisms are used for different pollutants - pesticides, heavy metals, phenolic compounds, organic waste, etc. Biosensing enables measurement of their concentration and their toxic or genotoxic effects on the microbes. Increasing environmental awareness has contributed to the increase of interest for biomonitoring. Although technologies, such as bioinformatics and genetic engineering, allow us to design complex and efficient microbial biosensors for environmental pollutants, the transfer of the laboratory work to the field still remains a problem to solve.

Key words: microbiology / environmental protection / microbial biosensors / environmental pollutants / microbial fuel cells / bioluminescence / genetics / bioinformatics / genetic engineering

\section{Mikrobni biosenzorji za monitoring okolja}

Mikrobni biosenzorji so analitske naprave, ki nam omogočajo zaznavanje snovi v okolju zaradi specifične biološke reakcije, ki poteka v mikroorganizmu ali njegovem delu. Če želimo takšno napravo uporabiti za monitoring onesnažil v okolju, moramo dobro poznati odziv mikroorganizma na specifičen analit in ga preko pretvornika signala spremeniti v kvantitativno obliko. Poznamo različne konfiguracije mikrobnih biosenzorjev glede na pretvornik signala - elektrokemijske in optične biosenzorje ter mikrobne gorivne celice. Vsaka ima svoje prednosti in slabosti, katero uporabimo, je v veliki meri odvisno od izbora biosenzorskega organizma. Transgene celice E. coli nam omogočajo bioluminescenčno ali fluorescenčno zaznavo, v mikrobne gorivne celice pa lahko vključimo mešane mikrobne združbe. Z izborom organizma se prilagajamo tudi onesnažilu. Med najpogostejšimi onesnažili so pesticidi, težke kovine, fenoli, organski odpadki. Z biosenzorji ne spremljamo le njihovih koncentracij v okolju, pač pa beležimo tudi toksične in genotoksične vplive analitov na mikroorganizme. S povečevanjem skrbi za okolje narašča tudi pomen mikrobnih biosenzorjev. Razvoj tehnologij, kot sta bioinformatika in genetski inženiring, nam omogoča temeljitejše in uspešnejše načrtovanje uporabe mikrobnih biosenzorjev v okoljskih aplikacijah. Izziv za prihodnje pa ostaja prenos mikrobne biosenzorske tehnologije na teren.

Ključne besede: mikrobiologija / varstvo okolja / mikrobni biosenzorji / okoljska onesnažila / mikrobne gorivne celice / bioluminescenca / genetika / bioinformatika / genetski inženiring

1 Univ. of Ljubljana, Biotechnical Fac., Dept. of Animal Science, Groblje 3, SI-1230 Domžale, Slovenia

2 Same address as 1

3 Same address as 1, e-mail: romana.marinsek@bf.uni-lj.si 


\section{INTRODUCTION}

A biosensor is a self-contained integrated device, capable of providing specific quantitative or semi-quantitative analytical information using a biosensing element connected with a transducer (IUPAC 1996, Thevenot et al., 2001). Biosensor construction, a three-step process, involves combining two elements with different characteristics. First, a biological sensing element is chosen, then a transducer is selected, and finally the biological component (detection element) is fixed to the transducer (Xu and Ying, 2011). Enzymes, antibodies, cell receptors, microorganisms, animal and plant cells or tissue cultures can be used as biorecognition components of a biosensor. Microorganisms have a huge potential for detection of a wide spectrum of chemical substances and their mixtures, they are adjustable to different reaction conditions and compared to enzymes or antibodies do not require expensive preparation processes (Shin 2010, Xu and Ying, 2011). They can be genetically modified, too. This characteristic enables the use of microbial biosensors in the fields of environmental monitoring, food safety and medicine.

\section{CHOICE AND APPLICATION OF A PROPER ORGANISM}

Choice of a proper microorganism for the detection of pollutants and their effects in the environment and its incorporation with the competent transducer is a key step in the development of an environmental biosensor. Bacteria and yeast are the most commonly used (Xu and Ying, 2011). The chosen microorganism must be robust and capable of specific pollutant detection in small concentrations, to ensure price efficient detection. Recently whole-cell biosensors (Chan et al., 2013; Niazi et al., 2008; Mulchandani and Rajesh, 2011; Anu Prathap et al., 2012) and microbial fuel cells (Di Lorenzo et al., 2014; Shen et al., 2013; Liu et al., 2014; Ayyaru and Dharmaligman, 2013) draw special attention on the field of environmental monitoring. Genetic engineering became important, too. We can manipulate organisms to improve mechanisms of analyte detection or express them in new organisms (Mulhandani and Rajesh, 2011). DNA segments coding for detection mechanisms can be transferred into model organisms with optimized growing conditions, such as Escherichia coli and Saccharomyces cerevisiae. The organism and the detection configuration should be combined properly to achieve the best possible detection of the signal.

\section{BIOSENSOR CONFIGURATION}

There are three main types of microbial biosensors classified, based on different signal transducers: electrochemical, optical and microbial fuel cells (Xu and Ying, 2011).

Electrochemical transducers use the change of the electric current, potential and conductivity, caused by microbial-analyte contact. They can be further divided into amperometric, potentiometric and conductometric biosensors. Amperometric microbial biosensors operate at a fixed potential with respect to a reference electrode, and then the corresponding current is obtained due to the oxidation or reduction of electroactive species at the surface of the electrode (Xu and Ying, 2011). This configuration has been described by Yong et al. (2011), Anu Prathap et al. (2012) and Wang et al. (2013); on the other hand, the potentiometric transducer was constructed by Mulchandani and Rajesh (2011). Transducers of this kind use ionselective electrodes to transmit the biological signal into an electric signal. They are less sensitive, produce higher relative error and a worse linear relationship between the exporting signal and the concentration of the detected analyte (Xu and Ying, 2011). As it is obvious from their name, conductometric biosensors measure changes in conductivity of the media, caused by the target analyte. Although the conductance measurements are extremely sensitive, the detection of solution conductance is considered to be nonspecific (Xu and Ying, 2011).

Optical biosensors can be defined as sensor devices that make use of optical principles, such as bioluminescence, fluorescence and colorimetry for transduction of a biochemical interaction into a suitable output signal (Xu and Ying, 2011). The use of genetic engineering enables an expression of fluorescence and bioluminescence in the target organism. Scientists report of luciferase (Niazi et al., 2008; Shin, 2010; Chan et al., 2013) and green fluorescent protein (GFP) applications (Wei et al., 2013; Kim et al., 2015). Microbial fuel cells (MFC) are bioelectrochemical devices that produce electrical energy through the action of specific microbes (known as anodophiles), capable of transferring the electrons generated from the oxidation of organic compounds (the fuel) to an anode electrode (Di Lorenzo et al., 2014). In a typical two-chamber MFC (Fig. 1), the electrons are absorbed by the anode and are transported to the cathode through an external circuit. After crossing a proton exchange membrane, the protons enter the cathodic chamber where they combine with oxygen to form water (Du et al., 2007). Electric current, produced by fuel oxidation, can serve as a transducer of a microbial response to the analyte. Due to their simple design and low cost, single-chamber MFC, where the cathode is exposed to air, are extensively used in envi- 


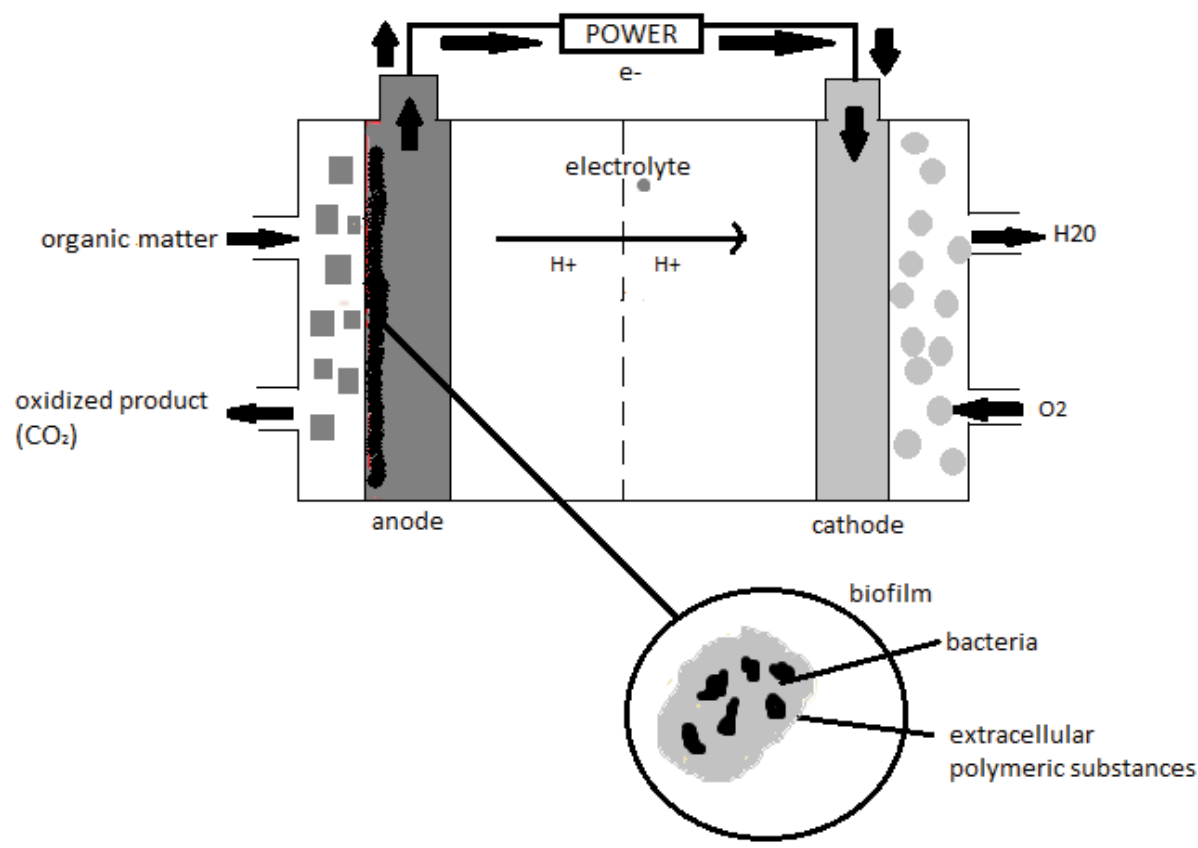

Figure 1: A scheme of a two-chamber microbial fuel cell

Slika 1: Shema dvoprekatne mikrobne gorivne celice

ronmental applications (Du et al., 2007). They are useful for the detection of biochemical oxygen demand (BOD) (Liu et al., 2013, Ayyaru and Dharmaligman, 2014), heavy metals and their toxicity (Shen et al., 2013; Liu et al., 2014; Di Lorenzo et al., 2014). MFC enable the use of heterogeneous microbial populations, isolated from wastewater plants and other working MFC. This characteristic makes them very successful for the development of sensitive, specific and cost efficient biosensors.

\section{ENVIRONMENTAL APPLICATIONS}

Organisations, like WHO and FAO, have realised the negative effect of pollutants on human health (BerezaMalcolm et al., 2015). Together with their concern grows the need for monitoring of dangerous substances in the environment. Pollutant residues can eventually accumulate in our food and drinking water. Food quality control systems are established to prevent that kind of cases. A biosensor, used instead of conventional chemical monitoring methods, must be easy to use, cost-efficient, stable when stored and capable of the detection of small amounts of the analyte. It must have a low detection limit and a short response time (Kumar et al., 2006). Transferring a working microbial biosensor under controlled laboratory conditions onto the field requires a lot of work and optimization. What follows is an overview of current trends in the field of environmental microbial monitoring.

\subsection{PESTICIDES}

Pesticides are chemical or biological substances meant for pests control. Considering the target organism, we can divide them into insecticides, herbicides, fungicides, bacteriocides, nematocides and others. The use of the first three listed above represent $95 \%$ of world consumption (Aktar et al., 2009). Insecticides are the most acute toxic group of pesticides. Their extensive use has a major environmental impact, resulting in water and ground accumulation. The negative effect of the pesticides rose awareness decades ago and led to the development of detection methods like gas and liquid chromatography for the monitoring of organophosphate pesticides. These methods have brought high selectivity and sensitivity, but are inappropriate for field detection, require expensive equipment and a skilled technician (Mulchandani and Rajesh, 2011). Furthermore, chemical analytical methods only provide the information of pesticide identity and quantity, but no information about their toxicity. Some biosensors are capable to detect pesticide toxicity and therefore they are suitable for their detection. Biosensors represent their alternative.

Kumar et al. (2006) report of an optical biosensor with bacteria Flavobacterium cells, adsorbed on the glass fiber. The cells express organophosphate hydrolase on their surface, an enzyme, capable of the hydrolysis of the organophosphate pesticides to the optically measurable colour products. Synthetic samples of the methyl 
parathion have been tested with the biosensor and a gas chromatography analysis. Biosensoric analysis was based on the ratio between the hydrolysed methyl parathion and the amount of the colourful product - p-nitrophenol. The methods have comparable results, but the biosensoric analysis is more cost-efficient. The developed biosensor showed a lower detection limit compared to other similar devices. The same detection principle of the p-nitrophenol as a hydrolysing product of the methyl parathion, was applied by Kumar and D’Souza (2010). They immobilized bacteria Sphingomonas JK1 on the bottom side of the microplate and linked them with an optical plate reader, to form an optical biosensor. This system enables multiple sample detection on one plate. Biosensor can detect 4-80 $\mu \mathrm{M}$ concentrations of methyl parathion and can be reused up to 75 times. Kumar and D'Souza (2011) also report of a recombinant E. coli, periplasmically expressing enzymes for methyl parathion hydrolysis, as a biorecognition element. Microbial cells were immobilized on a screen printed electrode, using glutaraldehyde. The researchers observed the changes in the electric current, caused by different concentrations of the methyl parathion. Biosensor showed good selectivity - it did not react to the addition of glucose, sucrose and endosulfan; the response to the phenol and p-aminophenyl sulfate was insignificant and had good stability - it preserved $80 \%$ of the enzymatic activity after being used in 32 reactions. Expression of the organophosphate hydrolase on the surface of the cells is efficient, its sensitivity can be improved by the application of the genetic engineering methods.

Recombinant biofilm forming bacteria Moraxella, containing the ICN protein from the Pseudosomonas syringae INA5, are capable of the detecting $1 \mu \mathrm{M}$ methyl parathion and $0.2 \mu \mathrm{M}$ paraoxon (Mulchandani and Rajesh, 2011). Overexpression of the linA2 gene, encoding the $\gamma$-hexachlorocyclohexane dehydrochlorinase (LinA2) in E. coli BL21, has been used by Anu Prathap et al. (2012) for the development of a sensitive, selective and fast electrochemical biosensor. LinA2 protein catalyses the dehydrochlorination of lindane into trichlorobenzene, forming $\mathrm{HCl}$ as a by-product and causing an increase in the conductivity of the cell microenvironment that can be detected with the pulse amperometry. Authors report about the detection limit of 2 ppt for lindane.

E. coli is among the most frequently used organisms in the field of microbial biosensors. A bioluminescent strain PGRFM, including luxCDABE operon and promotor region of the pgi gene, important for the metabolic answer to the oxidative stress, was applied by Niazi et al. (2008) for the construction of an optical biosensor. The sensor showed excellent response to the methyl viologen, pesticide that causes the induction of reactive oxygen species, with the detection limit of $0.6 \mathrm{ppm}$, when exposed to starving conditions. Another detection principle for the toxicity of ametryn, fenamiphos and endosulfan was reported by Yong et al. (2011). Amperometrically working ferricyanid was used as a redox probe to measure the overall toxicity of the chemicals on the E. coli respiration. Endosulfan was the most toxic, with the $\mathrm{IC}_{50}=5.7 \mathrm{mg} / \mathrm{L}$.

\subsection{HEAVY METALS}

Heavy metals are extensively used in several industry branches such as mining, metallurgical, electronics, electroplating and metalfinishing (Wang et al., 2013). The main threats to human health from heavy metals are associated with exposure to lead, cadmium, mercury and arsenic (Järup, 2003). Standard detection techniques - spectrometry, ionic chromatography, potentiometric electrodes - are expensive, sometimes time consuming and require high skilled technicians. Development of simple methods, suitable for field application, is the priority in the field of heavy metal analysis. Biosensor detection is among them.

Yüce et al. (2010) reported on the inclusion of the cyanobacterium Phormidium as the biosensing element of an amperometrical biosensor. Heat treated dead cyanobacterial biomass was mixed with carbon dust and added to a steal rod to form an electrode, capable of the detection of $\mathrm{Pb}$ (II) in water solution. The $\mathrm{Ag} / \mathrm{AgCl}$ reference electrode and platinum wire as counter electrode were also the part of the apparatus that measures the changes in the electric field, induced by heavy metal water solution. Results showed good stability and repeatability, a hypothetical limit of detection was set for $5 \mathrm{X}$ $10^{-8} \mathrm{M}$.

Microbial fuel cells (MFC) became important as well. The presence of a pollutant in wastewater can inhibit the metabolic activity of the electrochemically active bacteria, leading to the reduced electron transfer and weak current production. Single-chamber air-cathode MFC, enriched with real domestic wastewater have been applied by Shen et al. (2013) for the detection of $\mathrm{Cu}$ (II). They were interested in the response of a biofilm, formed by microorganisms in wastewater, at different flow rates. Higher feed rate causes higher shear rate in the surrounding of the MFC, leading to the overproduction of the extracellular polymeric substances and reduced biosensor sensitivity.

The effect of metals on microbes can be also measured with an oxidative stress biosensor. Ooi et al. (2015) constructed a biosensor, using E. coli $\mathrm{DH} 5 \mathrm{a}^{\mathrm{Tm}}$ transformed with pRSET-roGFP2 plasmid that enables fluorescent de- 
tection of arsenic induced oxidative stress. The biosensor is fast, efficient and enables detection down to $0.2 \mu \mathrm{g} / \mathrm{l}$ of arsenic. The same microorganism was used by AriasBarierro et al. (2010) for the detection of $\mathrm{Cd}^{2+}, \mathrm{Cu}^{2+}, \mathrm{Pb}^{2+}$, $\mathrm{Zn}^{2+}$ and arsenite. The described biosensor is even more sensitive and enables the detection down to $1^{\star} 10^{-7} \mathrm{mg} / \mathrm{l}$ arsenite, $0.001 \mathrm{ppm}$ copper and zinc ions, $0.01 \mathrm{ppm}$ cadmium ion and 5 ppm lead ions.

A continuous flow of the analyte to the biosensor is the most recent improvement in the field of biomonitoring. Kim et al. (2015) incorporated E. coli DH5 in a microfluidic device, capable of feeding nutrients and various concentrations of heavy metals ions under continuous-feed mode, for the detection of $\mathrm{Pb}^{2+}$ and $\mathrm{Cd}^{2+}$. The detection mechanism is based on the negative control of the GFP reporter gene, mediated by CadC-type transcriptional repressors, which bind to $\mathrm{Pb}^{2+}$ or $\mathrm{Cd}^{2+}$ divalent ions and derepress the GFP reporter promoters. They observed 3-4 fold increase in the sensitivity of the biosensor and good specificity dynamics to detect $\mathrm{Pb}^{2+}$ in $\mathrm{Cd}^{2+}$, comparing to conventional batch-type detection modes.

An alternative approach in the construction of a biosensor for the detection of heavy metal pollution on the field enables synthetic biology. The environmental pressure - oscillation in the temperature, $\mathrm{pH}$, access to the nutrients and toxicants in the environment affect a diverse set of regulatory elements, controlling the downstream signal cascade (Bereza-Malcolm et al., 2015). Microbial biosensor can be constructed de novo, using regulatory elements for the production of new genetic circuits. The authors estimate that this biosensor application can solve the problem of weak specificity and the toxic nature of heavy metals to the microbial chassis in real world applications.

\subsection{TOXICITY AND GENOTOXICITY}

The overall effect of the pollutants on the environment cannot be determined without an estimation of their toxicity. For the measurements of toxicity of water and ground samples, we use commercially developed tests - Mictorox ${ }^{\circledast}$ and ToxAlert ${ }^{\circledast}$ with Vibrio fischeri, Cellsense ${ }^{\varpi}$ with Escherichia coli (Rodriguez-Mozaz et al., 2004). They use fluorescent and amperometric detection. These systems no longer fulfil the need for monitoring of the toxicants in the environment, so the development of new methods is of great interest.

The secondary plant metabolites can show antimicrobial activity. Chan et al. (2013) developed two biosensors for the evaluation of aldehyde and phenolic terpenes and isothiocyanate on the microbes. The first biosensor combined the characteristics of commercial biosensors they used E. coli HB101 with the luxCDABE gene from $V$. fischeri, the other biosensor consisted of Acinetobacter baylyi ADP1_recA_lux, transformed with the luxCDABE gene from Photorhabdus luminescens. These transgenic bacteria produce light in the presence of toxicants, damaging the DNA; the intensity of the light is directly correlated with the recA expression level. RecA is an essential DNA repair gene. Isothiocyanate and cinnamaldehyde are the most toxic substances for E. coli - they mechanically damage plasmalemma, weaken the cell metabolism and the production of the energy, but they do not activate recA $A$. baylyi - it is less plausible that they damage the microbial genome.

Many studies examine the toxicity of heavy metals. An amperometrical microbial biosensor ToxTell applies different microbial species as a biosensing element, giving the optimal results of the toxicity of the real samples (Wang et al., 2013). The test organisms, Psychrobacter bacteria, isolated from the wastewater plant were immobilized on a polycarbonated screen printed electrode membrane. They investigated the toxicity of $\mathrm{Cu}^{2+}, \mathrm{Cd}^{2+}$, $\mathrm{Zn}^{2+}, \mathrm{Cr}^{6+}, \mathrm{Hg}^{2+}$ and $\mathrm{Pb}^{2+}$ to determine the $\mathrm{EC}_{50}$ value. The highest $\mathrm{EC}_{50}$ value was observed for $\mathrm{Pb}-110 \mathrm{mg} / \mathrm{l}$, the lowest for $\mathrm{Hg}-0.8 \mathrm{mg} / \mathrm{l}$. The toxicity of the metals increases with the decrease of particle size, as shown by Ivask et al. (2014). They investigated the toxicity of the silver nanoparticles, according to their size, to bacteria $E$. coli and Pseudomonas fluorescens, yeast S. cerevisiae and microalgae Pseudokirchneriella subcapitata. The latter showed the highest sensitivity. Liu et al. (2014) reported on the use of MFC as a real-time wastewater toxic shock biosensor. They monitored the response of the microbes, isolated from a wastewater plant, to the shocks of $\mathrm{Cr}^{6+}$, $\mathrm{Fe}^{3+}, \mathrm{NO}_{3}{ }^{-}$and sodium acetate. The growth of a biofilm on the anodic electrode was observed after five days. The biofilm enables the support and protection for electrogenic bacteria and improves the biosensor specificity - it can differentiate the chromium, iron, nitrate and sodium acetate shock. Single-chamber air-cathode MFC was used by Di Lorenzo et al. (2014) for the detection of cadmium. At optimal $\mathrm{pH}$ and temperature, the addition of cadmium in feeding water caused immediate change in the outgoing current. The biosensor enabled the detection of cadmium in the range of 1 to $50 \mu \mathrm{g} / \mathrm{l}$.

In an extensive study of the application of yeast in a hypersensitive biosensor, capable of automatic detection of a broad spectrum of genotoxic pollutants, Wei et al. (2013) used transformed and mutated S. cerevisiae BY4741 cells to establish their response on genotoxic chemicals (methyl sulfonyl methane (MMS), 4-nitroquinoline-oxide (4-NQO), phleomycin, hydrogen peroxide, tert butyl hydroperoxide methil viologen, chlorambucil 
Table 1: Overview of the biosensors, according to the target analyte, used microorganism, transducer type and detection specificity Preglednica 1: Pregled biosenzorjev po tarčnih analitih, uporabljenem mikroorganizmu, vrsti prevodnika in specifičnosti detekcije

\begin{tabular}{|c|c|c|c|c|}
\hline Analyte & Microorganism & $\begin{array}{l}\text { Transducer } \\
\text { type }\end{array}$ & $\begin{array}{l}\text { Detection limit (LOD), } \\
\mathrm{EC}_{50} \text { or } \mathrm{IC}_{50}\end{array}$ & Reference \\
\hline Methyl parathion & Flavobacterium & Optical & $\mathrm{LOD}=0.3 \mu \mathrm{M}$ & Kumar et al. (2006) \\
\hline Methyl parathion & Sphingomonas JK1 & Optical & $\begin{array}{l}\text { Detection range: } \\
4-80 \mu \mathrm{M}\end{array}$ & $\begin{array}{l}\text { Kumar and } \\
\text { D'Souza (2010) }\end{array}$ \\
\hline Methil parathion & Recombinant E. coli & Electrochemical & $\mathrm{LOD}=0.5 \mu \mathrm{M}$ & $\begin{array}{l}\text { Kumar and } \\
\text { D'Souza (2011) }\end{array}$ \\
\hline $\begin{array}{l}\text { Methyl parathion, } \\
\text { paraoxon }\end{array}$ & Recombinant Moraxella & Electrochemical & $\begin{array}{l}\text { Methil parathion: } \\
\text { LOD }=1 \mu \mathrm{M} \text {, } \\
\text { paraoxon: } \mathrm{LOD}=0.2 \mu \mathrm{M}\end{array}$ & $\begin{array}{l}\text { Mulchandani and } \\
\text { Rajesh (2011) }\end{array}$ \\
\hline Lindane & Recombinant E. coli BL21 & Electrochemical & $\mathrm{LOD}=2 \mathrm{ppt}$ & $\begin{array}{l}\text { Anu Prathap et al. } \\
(2012)\end{array}$ \\
\hline Methyl viologen & Recombinant E. coli & Optical & $\mathrm{LOD}=0.6 \mathrm{ppm}$ & Niazi et al. (2008) \\
\hline $\begin{array}{l}\text { DCP, ametryn, } \\
\text { endosulfan, fenamiphos }\end{array}$ & E. coli & Electrochemical & $\mathrm{IC}_{50}=5.7-22 \mathrm{mg} / \mathrm{L}$ & Yong et al. (2011) \\
\hline Lead & Phormidium & Electrochemical & $\mathrm{LOD}=2.5^{\star} 10^{-8} \mathrm{M}$ & Yüce et al. (2010) \\
\hline Copper & $\begin{array}{l}\text { Heterogeneous microbial } \\
\text { populations }\end{array}$ & MFC & $\mathrm{LOD}=5 \mathrm{ppm}$ & Shen et al. (2013) \\
\hline Arsenite, selenite & $\begin{array}{l}\text { Recombinant } E \text {. coli } \\
\text { DH5a }\end{array}$ & Optical & $\begin{array}{l}\text { Arsenite: } \mathrm{LOD}=0.2 \mu \mathrm{g} / \mathrm{l} \\
\text { selenite: } \mathrm{LOD}=5.8 \mathrm{ng} / \mathrm{l}\end{array}$ & Ooi et al. (2015) \\
\hline $\begin{array}{l}\text { Cadmium, copper, } \\
\text { lead, zinc, arsenite }\end{array}$ & $\begin{array}{l}\text { Recombinant E. coli } \\
\text { DH5 }{ }^{\text {TM }}\end{array}$ & Optical & $\begin{array}{l}\mathrm{Pb}: \mathrm{LOD}=5 \mathrm{ppm}, \\
\mathrm{Cd}: \mathrm{LOD}=0.01 \mathrm{ppm}, \\
\mathrm{Cu}, \mathrm{Zn}: \mathrm{LOD}=0.001 \mathrm{ppm}, \\
\text { arsenite: } \mathrm{LOD}=1^{*} 10^{-7} \mathrm{mg} / \mathrm{l}\end{array}$ & $\begin{array}{l}\text { Arias-Barierro et } \\
\text { al. }(2010)\end{array}$ \\
\hline Zinc, cadmium & Recombinant E. coli DH5 & Optical & / & Kim et al. (2015) \\
\hline $\begin{array}{l}\text { Isothiocyanate, } \\
\text { cinnamaldehyde }\end{array}$ & $\begin{array}{l}\text { Recombinant E. coli } \\
\text { HB101 }\end{array}$ & Optical & / & Chan et al. (2013) \\
\hline $\begin{array}{l}\text { Isothiocyanate, } \\
\text { cinnamaldehyde }\end{array}$ & $\begin{array}{l}\text { Recombinant Acinetobac- } \\
\text { ter baylyi ADP1 }\end{array}$ & Optical & l & Chan et al. (2013) \\
\hline $\begin{array}{l}\text { Copper, cadmium, zinc, } \\
\text { chromium, mercury, lead }\end{array}$ & Psychrobacter & Electrochemical & $\mathrm{EC}_{50}: 0.8-110.1 \mathrm{mg} / \mathrm{l}$ & Wang et al. (2013) \\
\hline Silver nanoparticles & $\begin{array}{l}\text { E. coli, } P \text {. fluorescens, } \\
\text { S. cerevisiae, } \\
\text { P. subcapitata }\end{array}$ & Optical & $\mathrm{EC}_{50}: 0.01-8.17 \mathrm{mg} / \mathrm{l}$ & Ivask et al. (2014) \\
\hline $\begin{array}{l}\text { Chromium, iron, nitrate, } \\
\text { sodium acetate }\end{array}$ & $\begin{array}{l}\text { Heterogeneous microbial } \\
\text { populations }\end{array}$ & MFC & l & Liu et al. (2014) \\
\hline Cadmium & $\begin{array}{l}\text { Electroactive mixed } \\
\text { bacteria }\end{array}$ & MFC & Detection range: $1-50 \mu \mathrm{g} / \mathrm{l}$ & $\begin{array}{l}\text { Di Lorenzo et al. } \\
(2014)\end{array}$ \\
\hline $\begin{array}{l}\text { MMS, 4-NQO, phleomy- } \\
\text { cin, hydrogen peroxide, } \\
\text { tert butyl hydroperoxide } \\
\text { methyl viologen, chlo- } \\
\text { rambucil and cisplatin }\end{array}$ & S. cerevisiae BY4741 & Optical & $\begin{array}{l}\text { 4-NQO: } \mathrm{LOD}=0.12 \mathrm{ng} / \mathrm{ml} \\
\text { MMS: } \mathrm{LOD}=0.36 \mu \mathrm{g} / \mathrm{ml}\end{array}$ & Wei et al. (2013 \\
\hline $\begin{array}{l}\text { Zinc, copper, 3,5-DCP, } \\
\text { benzene, toluene, bro- } \\
\text { nopol }\end{array}$ & $\begin{array}{l}\text { Recombinant E. coli } \\
\text { HB101 }\end{array}$ & Optical & $\mathrm{EC}_{50:} 0.09-21.0 \mathrm{mg} / \mathrm{l}$ & $\begin{array}{l}\text { Horsburgh et al. } \\
(2002)\end{array}$ \\
\hline Catechol & Lactobacillus & Electrochemical & $\begin{array}{l}\text { Detection range: } \\
0.5-5.0 \mathrm{mM}\end{array}$ & $\begin{array}{l}\text { Sagiroglu et al. } \\
\text { (2011) }\end{array}$ \\
\hline
\end{tabular}

Continued overleaf / nadaljevanje na naslednji strani 


\begin{tabular}{lllll}
\hline Salicylate & $\begin{array}{l}\text { Recombinant E. coli } \\
\text { DH5 } \alpha\end{array}$ & Optical & LOD $=0.1 \mu \mathrm{M}$ & Shin (2010) \\
\hline BOD & $\begin{array}{l}\text { P. putida SG10 } \\
\text { BOD }\end{array}$ & Electrochemical & $\begin{array}{l}\text { Detection range: } \\
0.5-10 \mathrm{mg} / \mathrm{l}\end{array}$ & Chee (2013) \\
& $\begin{array}{l}\text { Electroactive mixed } \\
\text { bacteria }\end{array}$ & MFC & $\begin{array}{l}\text { Detection range: } \\
100-750 \text { ppm }\end{array}$ & $\begin{array}{l}\text { Ayyaru and Dhar- } \\
\text { maligman (2014) }\end{array}$ \\
\hline BOD & $\begin{array}{l}\text { Heterogeneous microbial } \\
\text { populations }\end{array}$ & MFC & $\begin{array}{l}\text { Detection range: } \\
3-164 \text { ppm }\end{array}$ & $\begin{array}{l}\text { Di Lorenzo et al. } \\
(2014)\end{array}$ \\
\hline BOD & $\begin{array}{l}\text { Heterogeneous microbial } \\
\text { populations }\end{array}$ & Electrochemical & $\begin{array}{l}\text { Detection range: } \\
20-450 \mathrm{mg} / \mathrm{l}\end{array}$ & $\begin{array}{l}\text { Vaiopoulou et al. } \\
(2005)\end{array}$ \\
\hline
\end{tabular}

and cisplatin). Transcripts for RNR3 and HUG1 genes that work as a sensor due to their overexpression induced with DNA damage were linked with the yEGFP reporter gene, enabling the fluorescent detection. They report of improved detection at mutants with five or seven genes deleted. The highest sensitivity was observed with quintuple and septuple mutants. The septuple mutant of the HUG1 sensor gene showed the greatest sensitivity (relative sensitivity: $0.12 \mathrm{ng} / \mathrm{ml}$ for 4 -NQO and $0.36 \mu \mathrm{g} / \mathrm{ml}$ for MMS). Real-time monitoring is a key in the cases of large spills of toxicants to ensure an immediate response and reduce the negative effects on the environment (Di Lorenzo et al., 2014). On-line microbial biosensor can be used for automatized detection of toxicity. The E. coli HB101 cell suspension transformed with the pUCD607 plasmid with a lux CDABE insert was applied by Horsburgh et al. (2002) for the detection of the toxicity of environmental samples from a metal plating plant, a paper mill and a distillery. They constructed a pump system, enabling continuous flow of the cells, mixed with the samples to a light detection unit. This biosensor is sensitive on a broad spectrum of chemicals (zinc, copper, 3,5-DCP, benzene, toluene, bronopol), the $\mathrm{EC}_{50}$ values measured with a biosensor for zinc and bronopol were significantly more reliable than $\mathrm{EC}_{50}$ measured by batch mode in a cuvette. The biosensor of this kind enables quick and cheap making of environmental samples fingerprint, without the use of chemicals.

\subsection{PHENOLIC COMPOUNDS}

Phenolic compounds that appear in the environment originate from the paper and pulp industry and from the production of drugs, dyes, and antioxidants (Rodriguez-Mozaz et al., 2004). Lyophilised cells of the bacteria Lactobacillus, that were immobilised on a teflonmembrane oxygen electrode, work as a practical biosensor, suitable for the detection of catechol in wastewater and dairy products (Sagiroglu et al., 2011). The sensor measures the difference in the concentration of dissolved oxygen depending on the concentration of catechol and shows good sensitivity, substrate specificity, repeatability and cost-efficiency. Aromatic compounds raise special awareness due to their toxicity and environmental resistance. The microbial activation mechanism, triggering the NahR regulatory protein synthesis in the presence of salicylate, was used by Shin (2010) for the construction of a biosensor. The E. coli DH5a was transformed with a pNRSAL plasmid containing the nahR gene and luciferase reporter gene, for the bioluminescent detection of salicylate. The response of the mutants, introduced by side directed mutagenesis at the residues 169 and 248 of the nahR gene was compared to the response of the wild type organism. The substitution of the amino acids leads into drastic changes in the microbial response to salicylate, including the 50 -fold increase of sensitivity.

\subsection{BIOCHEMICAL OXYGEN DEMAND}

Biochemical oxygen demand $\left(\mathrm{BOD}\right.$ or $\mathrm{BOD}_{5}$ ) can be measured by a dedicated BOD test that applies aerobic microorganisms that consume the organic compounds in water systems for biochemical decomposition (Chee, 2013). BOD represents the oxygen used for neutralisation of organic compounds in 5 days, at $20^{\circ} \mathrm{C}$. Its conventional determination is time consuming and requests an expert to achieve repeatable results (Ayyaru and Dharmaligman, 2013). The use of biosensor enables us to avoid long-lasting incubation. They are mainly appropriate for the detection of BOD in samples with high concentration of easy-degradable organic compounds. Chee (2013) used five microorganisms ( $P$. putida SG10, P. fluorescens IAM12022, P. putida IAM1236, B. subtilis IAM12118, T.cutaneum IFO10466) that were immobilized on a porous cellulose-nitrate membrane of an oxygen electrode for the detection of BOD in river samples. All of the organisms were exposed to artificial wastewater and standard solutions of glucose and glutaminic acid. The most sensitive one ( $P$. putida SG10 with the detection limit of $0.5 \mathrm{mg} / \mathrm{l}$ ) was applied for the characterization of 
river samples. This biosensoric method is comparable with the determination of $\mathrm{BOD}_{5}$ by the standard method.

MFC are also suitable for the detection of BOD. Ayyaru and Dharmaligman (2014) report of a single chamber MFC, enriched with electrochemically active bacteria, isolated from the University of Anna water treatment plant as a suitable biosensor for the characterization of the unstable BOD. They monitored the electric current, produced by MFC at continuous feeding of the properly diluted samples of artificial wastewater. The anodic electrode senses the BOD as a current, produced by electrogenic bacteria, when in contact with organic compounds. A similar principle was used by Di Lorenzo et al. (2014) for the evaluation of a single-chamber aircathode MFC with multilayer 3D printing. MFC was enriched with heterogeneous microbial populations from another working MFC. They monitored the amperometrical response of the sensor on increasing concentration of acetate in water. The biosensor enabled a fast linear detection 3-164 ppm of chemical oxygen demand (due to the acetate, used in the study, it is similar to $\mathrm{BOD}_{5}$ )

The CO 2 concentration in gas phase, a by-product of microbial respiration activity during the catalysis of organic compounds, can be measured for the determination of current BOD values in wastewater samples. This principle was used by Vaiopoulou et al. (2005) for the development of a microbial biosensor, consisting of a conical fluidized bed reactor and cylindrical oxygen saturation chamber. The cell biomass from the activated sludge was used as an immobilized biosensing component. The biosensor was firstly calibrated in a laboratory with artificial wastewater with the addition of glucose and acetic acid and later used for the detection of BOD in a wastewater treatment plant Xianthi. The biosensor is adjustable for a broad range of wastewater.It enables the use of microbial populations from existing wastewater treatment plant and shows high activity of the immobilized cells, due to the continuous oxygen feeding.

\section{SUMMARY}

Microorganisms are appropriate biosensing elements for the construction of environmental pollutants biosensors. They are used for the detection of heavy metals, pesticides, phenolic compounds, BOD and toxicity or genotoxicity. MFC and whole cell biosensors are the most frequently used biosensor types. The development of genetic engineering enables organism manipulation and improved action of the sensory system. The majority of biosensors stated above, show excellent performance in laboratory conditions, but are not yet all optimized for field applications.

\section{REFERENCES}

Aktar W., Sengupta D., Chowdhury A. 2009. Impact of pesticides use in agriculture: their benefits and hazards. Interdisciplinary toxicology, 2: 1-12. doi:10.2478/v10102-0090001-7

Anu Prathap M.U., Chaurasia A.K., Sawant S.N., Apte S.K. 2012. Polyaniline-based highly sensitive microbial biosensor for selective detection of lindane. Analytical Chemistry, 84: 6672-6678. doi:10.1021/ac301077d

Arias-Barreiro C.R., Okazaki K., Koutsaftis A., Inayat-Hussain H.S., Tani A., Katsuhara M., Kimbara K., Mori I.C. 2010. A bacterial biosensor for oxidative stress using the constitutively expressed redox-sensitive protein roGFP2. Sensors, 10: 6290-6306. doi:10.3390/s100706290

Ayyaru S., Dharmalingam S. 2014. Enhanced response of microbial fuel cell using sulfonated poly ether ether ketone membrane as a biochemical oxygen demand sensor. Analytica Chimica Acta, 818: 15-22. doi:10.1016/j.aca.2014.01.059

Bereza-Malcolm L.T., Mann G., Franks A.E. 2015. Environmental sensing of heavy metals through whole cell microbial biosensors: a synthetic biology approach. ACS Synthetic Biology, 4, 5: 535-546. doi:10.1021/sb500286r

Chan A.C., Ager D., Thompson I.P. 2013. Resolving the mechanism of bacterial inhibition by plant secondary metabolites employing a combination of whole-cell biosensors. Journal of Microbiological Methods, 93: 209-217. doi:10.1016/j. mimet.2013.03.021

Chee G.-J. 2013. Development and characterization of microbial biosensors for evaluating low biochemical oxygen demand in rivers. Talanta, 117: 366-370. doi:10.1016/j.talanta.2013.09.031

Di Lorenzo M., Thomson A.R., Schneider K., Cameron P.J., Ieropoulos I. 2014. A small-scale air-cathode microbial fuel cell for on-line monitoring of water quality. Biosensors and Bioelectronics, 62: 182-188. doi:10.1016/j.bios.2014.06.050

Du Z., Li H., Gu T. 2007. A state of the art review on microbial fuel cells: A promising technology for wastewater treatment and bioenergy. Biotechnology Advances, 25: 464-482. doi:10.1016/j.biotechadv.2007.05.004

Horsburgh A.M., Mardlin D.P., Turner N.L., Henkler R., Strachan N., Glover L.A., Paton G.I., Killham K. 2002. On-line microbial biosensing and fingerprinting of water pollutants. Biosensors and Bioelectronics, 17: 495-501. doi:10.1016/ S0956-5663(01)00321-9

IUPAC. Compendium of chemical terminology. Gold book. Version 2.3.3. 2014: $1622 \mathrm{p}$.

Ivask A., Kurvet I., Kasemets K., Blinova I., Aruoja V., Suppi S., Vija H., Käkinen A., Titma T., Heinlaan M., Visnapuu M., Koller D., Kisand V., Kahru A. 2014. Size-dependent toxicity of silver nanoparticles to bacteria, yeast, algae, crustaceans and mammalian cells in vitro. PloS one, 9: 1-14. doi:10.1371/journal.pone.0102108

Järup L. 2003. Hazards of heavy metal contamination. British Medical Bulletin, 68: 167-182. doi:10.1093/bmb/ldg032

Kim M., Lim J.W., Kim H.J., Lee S.K., Lee J.L., Kim T. 2015. Chemostat-like microfluidic platform for highly sensitive detection of heavy metal ions using microbial biosensors. 
Biosensors and Bioelectronics, 65: 257-264. doi:10.1016/j. bios.2014.10.028

Kumar J., D'Souza S.F. 2010. An optical microbial biosensor for detection of methyl parathion using Sphingomonas sp. immobilized on microplate as a reusable biocomponent. Biosensors and Bioelectronics, 26: 1292-1296. doi:10.1016/j. bios.2010.07.016

Kumar J., D'Souza S.F. 2011. Microbial biosensor for detection of methyl parathion using screen printed carbon electrode and cyclic voltammetry. Biosensors and Bioelectronics, 26: 4289-4293. doi:10.1016/j.bios.2011.04.027

Kumar J., Kumar Jha S., D'Souza S.F. 2006. Optical microbial biosensor for detection of methyl parathion pesticide using Flavobacterium sp. whole cells adsorbed on glass fiber filters as disposable biocomponent. Biosensors and Bioelectronics, 21: 2100-2105. doi:10.1016/j.bios.2005.10.012

Liu B., Lei Y., Li B. 2014. A batch-mode cube microbial fuel cell based "shock" biosensor for waste water quality monitoring. Biosensors and Bioelectronics, 62: 308-314. doi:10.1016/j. bios.2014.06.051

Liu X., Du X., Wang X., Li N., Xu P., Ding Y. 2013. Improved microbial fuel cell performance by encapsulating microbial cells with a nickel-coated sponge. Biosensors and Bioelectronics, 41: 848-851. doi:10.1016/j.bios.2012.08.014

Mulchandani A., Rajesh. 2011. Microbial biosensors for organophosphate pesticides. Applied biochemistry and biotechnology, 165: 687-699. doi:10.1007/s12010-011-9288-x

Niazi J.H., Kim B.C., Ahn J.-M., Gu M.B. 2008. A novel bioluminescent bacterial biosensor using the highly specific oxidative stress-inducible pgi gene. Biosensors and Bioelectronics, 24: 670-675. doi:10.1016/j.bios.2008.06.026

Ooi L., Heng L.Y., Mori I.C. 2015. A high-throughput oxidative stress biosensor based on Escherichia coli roGFP2 cells immobilized in a k-carrageenan matrix. Sensors, 15: 2354 2368. doi:10.3390/s150202354

Rodriguez-Mozaz S., Marco M.-P., Lopez de Alda M., Barcelo D. 2004. Biosensors for environmental applications: Future development trends. Pure and applied chemistry, 76: $723-$ 752. doi:10.1351/pac200476040723

Sagiroglu A., Paluzar H., Ozcan H.M., Okten S., Sen B. 2011. A novel biosensor based on lactobacillus acidophilus for de- termination of phenolic compounds in milk products and wastewater. Preparative Biochemistry and Biotechnology, 41: 321-336. doi:10.1080/10826068.2010.540607

Shen Y., Wang M., Chang S., Ng H.Y. 2013. Effect of shear rate on the response of microbial fuel cell toxicity sensor to $\mathrm{Cu}(\mathrm{II})$. Bioresource Technology, 136: 707-710. doi:10.1016/j.biortech.2013.02.069

Shin H.J. 2010. Development of highly-sensitive microbial biosensors by mutation of the nahR regulatory gene. Journal of Biotechnology, 150: 246-250. doi:10.1016/j.jbiotec.2010.09.936

Thevenot D.R., Toth K., Durst R.A., Wilson G.S. 2001. Electrochemical biosensors: recommended definitions and classification. Biosensors and Bioelectronics, 16: 121-131. doi:10.1081/al-100103209

Vaiopoulou E., Melidis P., Kampragou E., Aivasidis A. 2005. On-line load monitoring of wastewaters with a respirographic microbial sensor. Biosensors and Bioelectronics, 21: 365-371. doi:10.1016/j.bios.2004.10.022

Wang X., Liu M., Wang X., Wu Z., Yang L., Xia S., Chen L., Zhao J. 2013. P-benzoquinone-mediated amperometric biosensor developed with Psychrobacter sp. for toxicity testing of heavy metals. Biosensors and Bioelectronics, 41: 557-562. doi:10.1016/j.bios.2012.09.020

Wei T., Zhang C., Xu X., Hanna M., Zhang X., Wang Y., Dai H., Xiao W. 2013. Construction and evaluation of two biosensors based on yeast transcriptional response to genotoxic chemicals. Biosensors and Bioelectronics, 44: 138-145. doi:10.1016/j.bios.2013.01.029

Xu X., Ying Y. 2011. Microbial Biosensors for Environmental Monitoring and Food Analysis. Food Reviews International, 27: 300-329. doi:10.1080/87559129.2011.563393

Yong D., Liu C., Yu D., Dong S. 2011. A sensitive, rapid and inexpensive way to assay pesticide toxicity based on electrochemical biosensor. Talanta, 84: 7-12. doi:10.1016/j.talanta.2010.11.012

Yüce M., Nazir H., Dönmez G. 2010. An advanced investigation on a new algal sensor determining $\mathrm{Pb}$ (II) ions from aqueous media. Biosensors and Bioelectronics, 26: 321-326. doi:10.1016/j.bios.2010.08.022 